\title{
Perfil editorial
}

La Revista nodo es una publicación semestral editada por la Facultad de Artes y la Vicerrectoría de Ciencia, Tecnología e Innovación (VCTI) de la Universidad Antonio Nariño (UAN), Bogotá, Colombia. Su objetivo es publicar artículos producto de investigación, relacionados con tres ejes temáticos: Arquitectura (diseño sustentable, arquitectura del paisaje, patrimonio, teoría, historia, crítica arquitectónica, tecnología y materiales). Ciudad (dimensión física de los asentamientos humanos y fenómenos sociales y culturales que se desarrollan en las ciudades). Hábitat (componentes bióticos y abióticos de áreas urbanas, periurbanas, regionales y territoriales).

La Revista nodo está dirigida a investigadores, docentes y estudiantes de diferentes campos de conocimiento, que incluyan dentro de sus objetivos la construcción y configuración de una mejor ciudad, tanto en sus dimensiones arquitectónicas y urbanas como en las sociales, culturales, ambientales y ecológicas.

revista.nodo@uan.edu.co

\section{Editorial profile}

nodo journal is published semiannually by the School of Arts and the Vice President Office for Science, Technology and Innovation (VCTI), of the Antonio Nariño University, Bogota, Colombia. It publishes research articles of these topics: Architecture (sustainable design, landscape architecture, heritage, theory, history, architecture criticism, technology and materials), City (physical dimensions of human settlements and social and cultural phenomena develop in the cities), and Habitat (biotic and abiotic components of urban, suburban, regional and territorial areas).

nodo journal is directed towards to those researchers, teachers and students, of different knowledge fields, that have a purpose in the construction and rearrangement of a better city from its architectural dimensions to the urban ones, like the social, cultural, environmental and ecological dimensions.

revista.nodo@uan.edu.co 